\title{
RMetS
}

Royal Meteorological Society

\section{Impact of different ozone sounding networks on a 4D-Var stratospheric data assimilation system}

\author{
F. Baier, ${ }^{\mathrm{a} \star}$ T. Erbertseder, ${ }^{\mathrm{a}}$ H. Elbern ${ }^{\mathrm{b}}$ and J. Schwinger ${ }^{\mathrm{c}}$ \\ ${ }^{a}$ German Aerospace Center (DLR), Earth Observation Center, Oberpfaffenhofen, Germany \\ ${ }^{\mathrm{b}}$ Rhenish Institute for Environmental Research, University of Cologne, Germany \\ ${ }^{\mathrm{c}}$ Geophysical Institute, University of Bergen, Norway
}

${ }^{\star}$ Correspondence to: F. Baier, German Aerospace Center, Oberpfaffenhofen, 82234 Wessling, Germany.

E-mail: frank.baier@dlr.de

\begin{abstract}
Observing system simulation experiments (OSSEs) are performed to examine the impact of ozonesonde observations on a data assimilation system during a simulated satellite data gap during February 2003. Using the four-dimensional variational chemical data assimilation system SACADA, the relative influence of launch rates and station coverage is investigated. Starting with the VINTERSOL/MATCH campaign, different network and sounding configurations are evaluated. To quantify the performance of assimilation experiments in the lower stratosphere, analysis skill and linear pattern correlation with respect to ERA-Interim reference data are assessed for the $20 \mathrm{~km}$ altitude level. Using first-guess and analysis minus observation error statistics, a priori error settings are tuned to optimise the assimilation of simulated and real-world ozone soundings. In summary, it is found that, during satellite data gaps, ozonesonde data can have a significant positive impact on the mean analysis skill depending both on the number of observations and the network layout. A better distributed network based on the GAW system, with 28 stations and three soundings bi-weekly, proves clearly superior to VINTERSOL/MATCH, showing a positive gain in skill of 0.26 compared to a free-running model. Copyright (C) 2013 Royal Meteorological Society
\end{abstract}

Key Words: data assimilation; polar stratospheric ozone; ozonesondes; satellite data

Received 24 February 2012; Revised 16 October 2012; Accepted 1 November 2012

Citation: Baier F, Erbertseder T, Elbern H, Schwinger J. 2013. Impact of different ozone sounding networks on a 4D-Var stratospheric data assimilation system. Q. J. R. Meteorol. Soc. DOI:10.1002/qj.2086

\section{Introduction}

Concerning stratospheric ozone, the coming years will suffer from a decrease of satellite instruments for vertically resolved ozone observations. For example, the ENVISAT platform has ceased operating recently. The current plans for new low earth-orbiting instruments foresee launch dates not before 2014-2015. (For example, Kerridge et al., 2005, provide an overview of planned satellite missions.) Therefore, it seems quite important to investigate the prospect for groundbased data as back-up or complementary data sources. Even with operational satellites, regular multi-week data gaps may appear, affecting data assimilation results.
Ozonesondes are an important independent source of information on the ozone layer up to $30 \mathrm{~km}$ altitude. They provide information at a high vertical resolution and are frequently used for the validation of satellite instruments or for monitoring chemical ozone depletion (e.g. Thompson et al., 2011). The Global Atmospheric Watch (GAW) program of the World Meteorological Organization (WMO) oversees an extensive ground-based monitoring system comprising (among other instruments) about 160 stations capable of launching ozonesondes. Other important but episodic sonde observations are provided by field campaigns. For example, during the Validation of International Satellites and study of Ozone Loss (VINTERSOL)/MATCH campaign (Streibel et al., 2006), more than 800 radiosondes from 34 
stations were launched between November 2002 and March 2003 to investigate chemical ozone loss. The GAW strategic plan for 2008-2015 (WMO, 2007) asks for the possibility of directly assimilating ground-based observations to be investigated.

In general, ozonesonde observations are reliable and result in data of high quality (e.g. WCRP, 1998). However, spatial coverage of stations is rather sparse with a strong focus on North America and Western Europe. Currently, for example, only about 15 stations provide data to the World Ozone and UV Data Center (WOUDC; http://www.woudc.org) on a regular basis, i.e. perform between two and three soundings per week. Thus, the application of ozonesondes for routine data assimilation is currently limited by the inhomogeneous distribution of stations and/or poor sounding rates. Data gathered by regular ozone soundings are therefore mainly used for monitoring of lower-stratospheric ozone trends and validation of co-located satellite observations (Deniel et al., 1997; Meijer et al., 2004; Borchi and Pommereau, 2007; Nassar et al., 2008).

During recent years, assimilation of satellite-based ozone data into global chemical-transport models (CTMs) has become the state-of-the-art method to generate global stratospheric concentration and total column fields (e.g. Levelt et al., 1998; Errera and Fonteyn, 2001; Eskes et al., 2003; Baier et al., 2005; Elbern et al., 2010; Schwinger and Elbern, 2010). Besides compliance monitoring of the ozone layer, stratospheric ozone analyses are used for a wide range of applications, e.g. to improve long-term weather forecasts (Peuch et al., 2000; Charlton et al., 2004) or to help in the interpretation of climate model results (Eyring et al., 2005). For an extensive review of stratospheric constituent assimilation, we refer to Lahoz et al. (2007). With respect to spatial resolution and sampling rate, recent operational limb-sounding instruments like the Microwave Limb Sounder (MLS) on board the AURA satellite (Waters et al., 2004) and the Michelson Interferometer for Passive Atmospheric Sounding (MIPAS) on board the ENVISAT platform (Fischer and Oelhaf, 2005) can fulfill requirements of state-of-the-art CTMs to generate daily global analyses with short time lags (in general within $24 \mathrm{~h}$ of data acquisition).

Here, we will investigate the potential of ozonesonde observations to fill a (simulated) satellite data gap during February 2003. Therefore, starting with the VINTERSOL/MATCH campaign, several station network configurations with different sounding rates are simulated using the experimental set-up of an Observation System Simulation Experiment (OSSE). We limit our study to the Northern Hemisphere (NH) lower stratosphere of February 2003 as it is well covered by both ozonesondes and satellite data. During this period, increased dynamic variability due to a minor warming event as well as significant chemical ozone depletion could be observed (e.g. Kuttippurath, 2011). We choose the $55.4 \mathrm{hPa}$ model level $(\approx 20 \mathrm{~km}$ altitude) as a proxy for model performance in the lower winter stratosphere, well within the reach of both ozonesondes and satellites.

Observation system simulation experiments (OSSEs) allow the assessment of the impact of different observing system designs or instrumentation on data assimilation (e.g. Masutani et al., 2010). Full OSSEs use a free-running independent model to generate observations and reference fields for evaluation. In the following, we employ a modified OSSE approach where ozonesonde observations are replaced by simulated observations based on ERAInterim global reanalysis (Dee et al., 2011). Applying an analysis contrary to a free-running model is justified by the exceptional atmospheric evolution of February 2003. Thus, an accurate depiction of the actual atmospheric state was mandatory. By using daily analyses derived by an independent model, it is hoped that the so-called 'incest problem' is minimized. Our approach is therefore similar to that of (Lahoz et al., 2005) which described a reduced OSSE based on daily global analyses. The validity of using simulated ozonesonde data is checked by comparison with assimilation results based on VINTERSOL/MATCH ozonesonde data. Together with a free model run, ERAInterim thus serves as a reference experiment to assess changes of the analysis skill due to different instruments used and, with respect to ozonesondes, different station network configurations.

Section 2 explains the choice and application of input data and its main characteristics. An overview of the fourdimensional variational data assimilation (4D-Var) system SACADA (Synoptic Analysis of Chemical constituents by Advanced Data Assimilation) is given in section 3. Section 4 discusses the overall experimental set-up and the OSSE approach. Experiments fall into two categories: (i) assimilation of ENVISAT Michelson Interferometer for Passive Microwave Sounding (MIPAS) satellite observations and, alternatively, VINTERSOL/MATCH ozonesonde soundings, and (ii) assimilation of different (virtual) ozonesonde station networks with changes to station coverage and sounding rates based on ERA-Interim reanalysis. Set-up and tuning of the assimilation system to accommodate the different types of observations used are described in section 5 . Section 6 briefly discusses lower-stratospheric ozone variability in the NH during February 2003. In section 7 the main results of the assimilation experiments are presented. The final section 8 provides conclusions and gives some recommendations for further work.

\section{Assimilation data}

As sample data for the application of satellite data, we use MIPAS satellite observations: the MIPAS instrument gives nearly global coverage within several days and has a reasonable vertical resolution. For comparison, VINTERSOL ozonesonde observations are sparse but provide high vertical resolution and data quality. We assimilate VINTERSOL data to investigate the potential to substitute satellite data during a one-month period. As reference data for observing system experiments, we use ozone fields from the ERA-Interim (ERA-I) global atmospheric reanalysis. In the next section we describe details of the ERA-I data used, followed by respective sections on MIPAS and VINTERSOL observations.

The ERA-I reanalysis is produced by the European Centre for Medium-Range Weather Forecasts (ECMWF) by assimilation of observations from ground-based and satellite instruments. ERA-I currently covers the period from 1989 onwards and is planned to supersede the ERA-40 forty-year reanalysis (Dee et al., 2011). The analysis is based on the 60-level version of ECMWF's Integrated Forecast System (IFS) with 4D-Var assimilation of atmospheric observations including ozone. The atmospheric data product provided has a $6 \mathrm{~h}$ temporal resolution and a maximum spatial 
Table 1. Overview of station and ozonesonde data used for this study including station locations and total number of ozonesonde launches during February 2003 made for the networks VINT (original VINTERSOL network), VINTx2 (simulated with doubled sounding frequencies) and GAW (simulated to test for increased station coverage). Sections 2 and 4 provide details.

\begin{tabular}{|c|c|c|c|c|c|c|}
\hline \multirow{2}{*}{$\begin{array}{l}\text { Latitude } \\
\qquad\left({ }^{\circ} \mathrm{N}\right)\end{array}$} & \multirow[t]{2}{*}{ Longitude } & \multirow[t]{2}{*}{ Station } & \multirow[t]{2}{*}{ Country } & \multicolumn{3}{|c|}{ No. of ozonesonde launches } \\
\hline & & & & VINT & VINTx2 & GAW \\
\hline 50.80 & $4.35^{\circ} \mathrm{E}$ & Uccle & Belgium & 13 & 26 & -- \\
\hline 82.50 & $62.30^{\circ} \mathrm{W}$ & Alert & Canada & 8 & 16 & 6 \\
\hline 58.74 & $94.07^{\circ} \mathrm{W}$ & Churchill & Canada & 5 & 10 & 6 \\
\hline 53.55 & $114.11^{\circ} \mathrm{W}$ & Edmonton & Canada & 3 & 6 & 6 \\
\hline 79.98 & $85.93^{\circ} \mathrm{W}$ & Eureka & Canada & 6 & 12 & -- \\
\hline 53.32 & $60.30^{\circ} \mathrm{W}$ & Goose Bay & Canada & 4 & 8 & -- \\
\hline 74.72 & $94.98^{\circ} \mathrm{W}$ & Resolute & Canada & 5 & 10 & 6 \\
\hline 43.78 & $79.47^{\circ} \mathrm{W}$ & Toronto & Canada & -- & -- & 6 \\
\hline 49.90 & $97.24^{\circ} \mathrm{W}$ & Winnipeg & Canada & -- & -- & 6 \\
\hline 44.75 & $127.60^{\circ} \mathrm{E}$ & Longfenshan & China & -- & -- & 6 \\
\hline 50.02 & $14.45^{\circ} \mathrm{E}$ & Prague & Czech Republic & 12 & 24 & -- \\
\hline 67.40 & $26.60^{\circ} \mathrm{E}$ & Sodankylä & Finland & 9 & 18 & -- \\
\hline 47.80 & $11.02^{\circ} \mathrm{E}$ & Hohenpeissenberg & Germany & 12 & 24 & -- \\
\hline 52.21 & $14.12^{\circ} \mathrm{E}$ & Lindenberg & Germany & 5 & 10 & -- \\
\hline 40.52 & $22.97^{\circ} \mathrm{E}$ & Thessaloniki & Greece & -- & -- & 6 \\
\hline 70.50 & $22.00^{\circ} \mathrm{W}$ & Scoresbysund & Greenland & 6 & 12 & 6 \\
\hline 76.52 & $68.76^{\circ} \mathrm{W}$ & Thule & Greenland & 4 & 8 & 6 \\
\hline 51.93 & $10.25^{\circ} \mathrm{W}$ & Valentia & Ireland & 3 & 6 & -- \\
\hline 41.90 & $12.52^{\circ} \mathrm{E}$ & Rome & Italy & -- & -- & 6 \\
\hline 78.93 & $11.88^{\circ} \mathrm{E}$ & Ny-Ålesund & Norway & 17 & 28 & 6 \\
\hline 63.42 & $9.24^{\circ} \mathrm{E}$ & Ørland & Norway & 4 & 8 & -- \\
\hline 59.91 & $10.72^{\circ} \mathrm{E}$ & Oslo & Norway & -- & -- & 6 \\
\hline 52.40 & $20.97^{\circ} \mathrm{E}$ & Legionowo & Poland & 5 & 10 & -- \\
\hline 64.58 & $40.50^{\circ} \mathrm{E}$ & Arkhangelsk & Russia & -- & -- & 6 \\
\hline 73.50 & $80.23^{\circ} \mathrm{E}$ & Dikson Island & Russia & -- & -- & 6 \\
\hline 52.26 & $104.35^{\circ} \mathrm{E}$ & Irkutsk & Russia & -- & -- & 6 \\
\hline 55.75 & $37.57^{\circ} \mathrm{E}$ & Moscow & Russia & -- & -- & 6 \\
\hline 65.12 & $57.10^{\circ} \mathrm{E}$ & Pechora & Russia & -- & -- & 6 \\
\hline 52.97 & $158.75^{\circ} \mathrm{E}$ & Petropavlovsk & Russia & -- & -- & 6 \\
\hline 66.70 & $66.70^{\circ} \mathrm{E}$ & Salekhar & Russia & 8 & 16 & -- \\
\hline 43.12 & $131.90^{\circ} \mathrm{E}$ & Vladivostok & Russia & -- & -- & 6 \\
\hline 62.08 & $129.75^{\circ} \mathrm{E}$ & Yakutsk & Russia & 6 & 12 & 6 \\
\hline 46.30 & $14.53^{\circ} \mathrm{E}$ & Mount Krvavec & Slovenia & -- & -- & 6 \\
\hline 40.45 & $3.72^{\circ} \mathrm{W}$ & Madrid & Spain & -- & -- & 6 \\
\hline 50.40 & $30.45^{\circ} \mathrm{E}$ & Kiev & Ukraine & -- & -- & 6 \\
\hline 60.13 & $1.18^{\circ} \mathrm{W}$ & Lerwick & UK & 4 & 8 & -- \\
\hline 57.73 & $4.78^{\circ} \mathrm{W}$ & Strath Vaich & UK & -- & -- & 6 \\
\hline 71.32 & $156.60^{\circ} \mathrm{W}$ & Barrow & USA & -- & -- & 6 \\
\hline 46.87 & $68.03^{\circ} \mathrm{W}$ & Caribou & USA & -- & -- & 6 \\
\hline 64.82 & $147.87^{\circ} \mathrm{W}$ & Fairbanks & USA & -- & -- & 6 \\
\hline
\end{tabular}

resolution of approximately $79 \mathrm{~km}$. However, the ozone analysis is driven by IFS, and there is currently no direct feedback into the dynamical model (Dethof and Hólm, 2004). The prognostic ozone forecast uses a linearized ozone chemistry scheme based on (Cariolle and Déqueé, 1986). (Dragani, 2011) compared ERA-I ozone to independent satellite instruments. For the NH lower stratosphere during 2003, they found generally a good correspondence with observations, with monthly mean differences between 0 and $-10 \%$. However, a comparison to in-situ data by (Dragani, 2010) showed a positive bias of $10 \%$ at the $50 \mathrm{hPa}$ level. As MIPAS observations have been actively assimilated during this period, the latter result would be consistent with the findings of (Cortesi et al., 2007) and (Stiller et al., 2012).

MIPAS is a limb-sounding instrument on board the European ENVISAT platform, which was launched into a polar low earth orbit in March 2002 (Fischer and Oelhaf,
2005). The instrument's coverage is nearly global with about 1000 profile observations per day. From MIPAS observations, six trace gases are nominally processed for the altitude range between 6 and $68 \mathrm{~km}$ with a vertical step size between 3 and $6 \mathrm{~km}$. Due to ENVISAT's sun-synchronous orbit, local observation times are fixed. For example, on the day side, near-Equator measurements are performed about 0600 UTC. While the instrument's field of view is about $3 \times 30 \mathrm{~km}$ at the tangent point, the true horizontal resolution is limited to approximately $400 \mathrm{~km}$ along the line of sight (Stiller et al., 2002). In the lower stratosphere, comparisons to independent ozone observations (Bracher et al., 2004; Cortesi et al., 2007; Stiller et al., 2012) show typical r.m.s. (root mean square) errors between 5 and $15 \%$ with increasing deviations below $20 \mathrm{~km}$ altitude. In general, the bias is positive with maximum error levels of $10 \%$. As was shown by several assimilation studies based on 


\section{F. Baier et al.}

ENVISAT MIPAS data, the coverage of MIPAS observations between July 2002 and March 2004 is suited for chemical data assimilation. Assimilation results (analyses) for stratospheric ozone compare well to independent data showing small bias and standard deviation between 10 and $20 \%$ with a higher uncertainty in the lower stratosphere (e.g. Geer et al., 2006; Erbertseder et al., 2007; Errera et al., 2008). For the purpose of this study, we process daily MIPAS observations from 9 January onwards. They cover February 2003 with only 21 and 22 February missing. We use MIPAS off-line level 2 data product version 4.61 (Cortesi et al., 2007) from the European Space Agency covering the standard species: $\mathrm{O}_{3}$, $\mathrm{H}_{2} \mathrm{O}, \mathrm{HNO}_{3}, \mathrm{CH}_{4}, \mathrm{~N}_{2} \mathrm{O}$ and $\mathrm{NO}_{2}$.

Contrary to the permanent station networks like GAW, dedicated to long-term monitoring, sounding activities during observation campaigns focus on short-term and seasonal ozone changes. VINTERSOL was a major panEuropean observing campaign, which took place between 2002 and 2004 (Harris and Amanatidis, 2003). Part of VINTERSOL was the MATCH balloon campaign addressing stratospheric ozone depletion during the Arctic winter 2002/2003 (Streibel et al., 2006). To assess the chemical ozone loss along the vortex edge, a great number of MATCH soundings were performed on request to capture identical air parcels. Thus active stations were concentrated at high latitudes and Northern Europe (Figure 1(a)). For this study we use VINTERSOL/MATCH covering February 2003. It consists of 20 active stations north of $40^{\circ} \mathrm{N}$ providing a total of 139 soundings. This gives an average sounding rate of one flight within 4 days per station. For convenience we will refer in the following to these data as 'VINTERSOL' soundings.

Figure 1(a) shows the coverage of the VINTERSOL ozonesonde launches during February 2003, while Table 1 gives the station locations and respective sounding rates. The size of circles in Figure 1(a) indicates the total number of ozone profiles observed at a particular site. The number of observations varies significantly between the sites. For example, while station Ny-Ålesund accomplished a total of 17 soundings, Edmonton reported only three sonde launches for the same time period. Contrary to satellite-based observations, in situ measurements made by ozonesondes depend on the individual performance of the instrument at hand, the skill of operators and operating procedures (WMO, 2011). The major types of ozonesonde currently flown are based on the reaction of ozone with potassium iodide within an electro-chemical cell. Although in general the individual instruments show a high level of precision, systematic differences between instruments can be significant (WCRP, 1998). A recent intercomparison of electrochemical concentration cell (ECC) sondes under controlled conditions revealed significant biases between 5 and $10 \%$ for the lower stratosphere (Smit et al., 2007). The general precision of ozonesonde measurements was found to be in general at the 3 to $5 \%$ level. The largest errors occur near the maximum altitude of operation at $30-35 \mathrm{~km}$. A typical measurement takes between 1 and $2 \mathrm{~h}$ to reach the maximum altitude with a vertical resolution better than $100 \mathrm{~m}$. Depending on the weather situation, the horizontal instrument drift can add up to several hundred $\mathrm{km}$.

\section{Description of the assimilation system SACADA}

To demonstrate the potential of ground-based ozone soundings for data assimilation within the $\mathrm{NH}$ stratosphere, we use the state-of-the-art global 4D-Var data assimilation system SACADA version 2 (Elbern et al., 2010). SACADA includes the German Weather Services global forecast model GME (Majewski et al., 2001) as a meteorological driver module which generates a $24 \mathrm{~h}$ forecast of the dynamical fields that drive the SACADA chemistry-transport model. As both modules utilise the same icosahedral grid with hybrid sigma-pressure vertical coordinates, consistency of dynamical fields is guaranteed. The CTM includes a comprehensive stratospheric chemistry mechanism, and utilises a semi-Lagrange scheme for the horizontal advection and an implicit upstream scheme for the vertical transport. The chemical system treats the interaction of 48 stratospheric constituents in 167 gas phase and 10 heterogeneous reactions. Heterogeneous processes on sulphate aerosol droplets and polar-stratospheric clouds (PSCs) are accounted for according to Damski et al.(2007), including sedimentation of $\mathrm{H}_{2} \mathrm{O}$ and $\mathrm{HNO}_{3}$ in condensed phase. For data assimilation purposes, an adjoint CTM has been implemented. A detailed description of SACADA, as well as an evaluation of the system for assimilation of ENVISAT MIPAS observations during selected periods in 2002 and 2003, can be found in (Elbern et al., 2010) and (Schwinger and Elbern, 2010). Currently, SACADA is run operationally at the German Aerospace Center to assimilate ozone observations from the instruments GOME-2 (Observation Global Ozone Monitoring Experiment-2) and SCIAMACHY (Scanning Imaging Absorption Spectrometer for Atmospheric Chemistry) on the satellites MetOp and ENVISAT. For this study we use a horizontal grid resolution of approximately $250 \mathrm{~km}$ and a vertical step size of $1.3 \mathrm{~km}$ for the lowermost stratosphere. In its current configuration, the CTM consists of 32 model levels between 7 and $66 \mathrm{~km}$ altitude.

The variational assimilation system minimises a global cost function taking into account background and observational errors depending on the distance of model background and observations to the analysis. Minimisation is done by calculation of the cost function gradient with respect to a control variable (Talagrand, 1997). In chemical 4D-Var, the control vector covers the initial concentrations of observed species. The relative influence of background and observational errors is controlled via background and observational covariances. In SACADA, the spatial background covariances are calculated following the diffusion approach of (Weaver and Courtier, 2001). Though this approach allows for a flow-dependent and anisotropic correlation matrix (Elbern et al., 2010), here we assume a fixed correlation length-scale and use fixed a priori relative background errors for all experiments (section 4 and Appendix A give details on the a priori error settings). The assimilation model set-up is similar to the one used by (Schwinger and Elbern, 2010) who evaluated the performance of the SACADA version 2 data assimilation system using MIPAS ESA standard observations and independent data during the Austral spring of 2003. For the minimisation of the cost function, we use a $24 \mathrm{~h}$ assimilation window and limit the number of iterations to five. This is a reasonable value given the sequential application of daily analyses, i.e. the model is initialized by the results of the last forward iteration from the day before. 

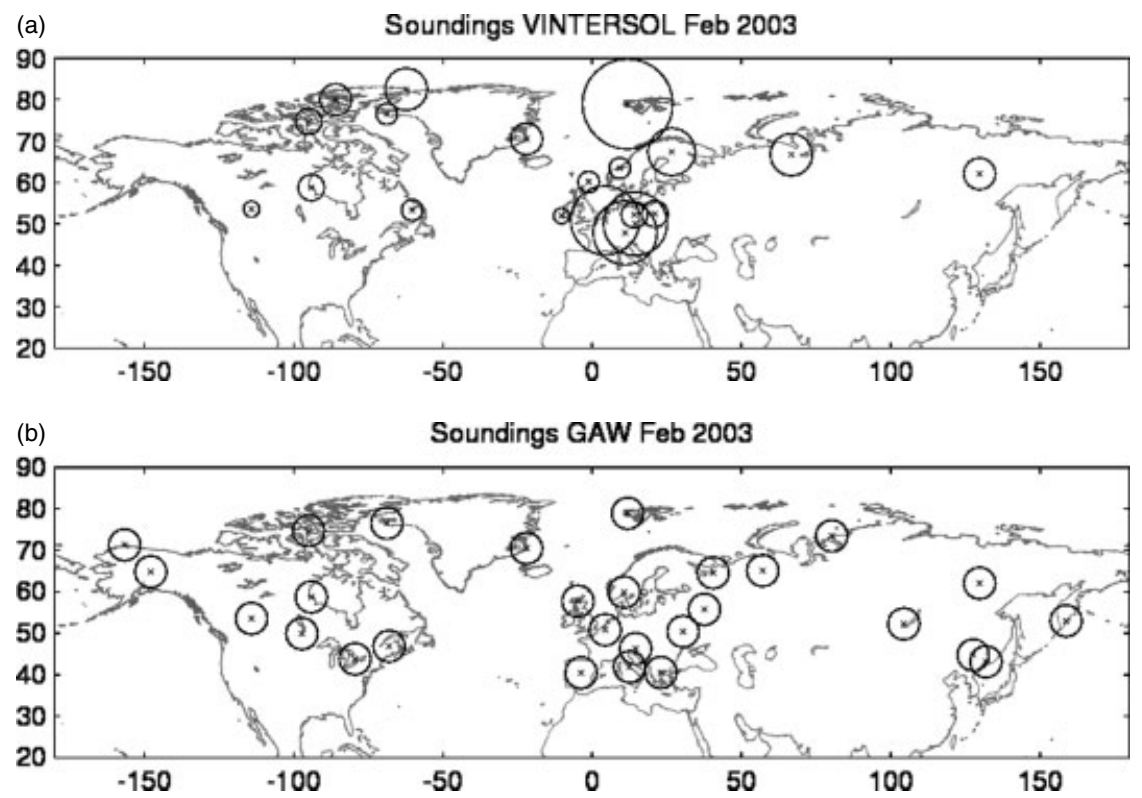

Figure 1. Distribution of active ozonesonde stations during February 2003 used for (a) the VINTERSOL/MATCH campaign and (b) the virtual GAW network, as defined for this study (Table 1). The individual circle size indicates the total number of soundings during February 2003. For (a), the maximum number of 17 soundings was reached at Ny-Ålesund (Norway). For Edmonton (Canada), only three soundings were available. For (b), the sounding rate was fixed to six soundings per month and station.

Table 2. Overview of all data assimilation experiments performed for this study, covering the period from 1 to 28 February 2003. Experiments are grouped as follows: free running model (FR), reference experiments, i.e. non-OSSEs (A1, A2) and OSSEs (O1, O2, O3). References refer mainly to the instrument validation with respect to ozone. Section 2 provides details on the assimilated data products. Table 1 shows the ozonesonde station coverage and sounding rates of the three network configurations VINT, VINTx2 and GAW. n.a. = not applicable.

\begin{tabular}{|c|c|c|c|c|}
\hline Experiment & Assimilated data & $\begin{array}{l}\text { No. of } \\
\text { profiles }\end{array}$ & Data reference & Comment \\
\hline FR & none & n.a. & $\begin{array}{l}\text { n.a., } \\
\text { see section } 4\end{array}$ & $\begin{array}{l}\text { Free model run, } \\
\text { initialization as A1 }\end{array}$ \\
\hline A1 & $\begin{array}{l}\text { MIPAS: } \mathrm{O}_{3}, \mathrm{H}_{2} \mathrm{O}, \mathrm{HNO}_{3} \text {, } \\
\mathrm{CH}_{4}, \mathrm{~N}_{2} \mathrm{O}, \mathrm{NO}_{2}\end{array}$ & 21055 & Carli et al. (2004) & $\begin{array}{l}\text { ENVISAT/MIPAS } \\
\text { limb profiles v4.61 }\end{array}$ \\
\hline A2 & VINTERSOL ozone profiles & 139 & Streibel et al. (2006) & $\begin{array}{l}\text { Ozonesonde data from } \\
\text { the MATCH campaign }\end{array}$ \\
\hline 01 & ERA-Interim ozone, with VINT & 139 & Dee et al. (2011) & $\begin{array}{l}\text { As A2 but with ozone } \\
\text { profiles from ERA-I }\end{array}$ \\
\hline $\mathrm{O} 2$ & ERA-Interim ozone, with VINTx2 & 272 & Dee et al. (2011) & $\begin{array}{l}\text { As } \mathrm{O} 1 \text { but with } \\
\text { increased sounding rates }\end{array}$ \\
\hline O3 & ERA-Interim ozone, with GAW & 168 & Dee et al. (2011) & $\begin{array}{l}\text { As O1 but based on } \\
\text { GAW station network }\end{array}$ \\
\hline
\end{tabular}

\section{Experimental set-up}

In the following, we describe the general set-up of experiments including OSSEs. Table 1 lists the active stations during February 2003 and their locations for the three different network configurations used and the number of soundings per station. In the following we use the term 'network' to depict a certain station list and observation schedule. Table 2 gives an overview of all experiments, while Table 3 shows respective scoring results and gives additional coverage information.

Experiments cover 1 to 28 February 2003. All experiments start with results from a model spinup covering January 2003. For the spin-up, the CTM was initialised with 2D SOCRATES chemical fields for January conditions extracted from a 10-year run (http://acd.ucar.edu/models/SOCRATES). Because we would like to investigate the prospect for ozonesondes to fill satellite data gaps, the spin-up was constrained by assimilation of MIPAS observations from 9 January onwards. Since the meteorological module of SACADA generates its own $24 \mathrm{~h}$ forecast, operational meteorological analyses of the ECMWF were applied for model initialization once per day. As is shown by Table 2, experiments fall basically into two categories: first, assimilation of all available MIPAS data (A1) and, alternatively, VINTERSOL ozonesonde soundings (A2), and second, assimilation of 'virtual' ozonesonde data based on ERA-I with different daily sounding rates (O2) and station coverage (O3). A free model run without any assimilation at all (FR) is used as reference for the skill analysis (Table 4). Note that the free run uses the same initialization as the other experiments. For the purpose of this study, we will 
Table 3. Overview of assimilation experiments, input data, data coverage and performance results for $20 \mathrm{~km}$ altitude ozone mixing ratios covering all days of February 2003. The Area affected was calculated by integrating the area within a station influence radius of $100 \mathrm{~km}$. For the MIPAS experiment (A1) this was done on the basis of limb profile observations north of $30^{\circ} \mathrm{N}$, for 1 February with a total of 913 profiles. The Mean Pearson Correlation (MPC) was calculated by summing over correlations of individual grid points north of $30^{\circ} \mathrm{N}$. Correlation and error scores are given with respect to ERA-I reanalysis. For the skill score, the free run (FR) is used as the reference. Appendix B gives the definition of $\chi^{2}$ and scoring parameters. Abbreviations are as in Table 2.

\begin{tabular}{|c|c|c|c|c|c|c|c|c|c|}
\hline Experiment & Network & Input data & $\begin{array}{l}\text { No. of } \\
\text { stations }\end{array}$ & $\begin{array}{c}\text { Area } \\
\text { affected } \\
\left(10^{3} \mathrm{~km}^{2}\right)\end{array}$ & $\begin{array}{c}\text { No. of } \\
\text { soundings }\end{array}$ & $\begin{array}{l}\text { NMB } \\
(\%)\end{array}$ & $\begin{array}{l}\text { FGE } \\
(\%)\end{array}$ & MPC & $\begin{array}{l}\text { Skill } \\
\text { score }\end{array}$ \\
\hline FR & n.a. & none & n.a. & 0 & 0 & -4.64 & 11.08 & 0.65 & 0.0 \\
\hline A1 & n.a. & MIPAS & 305 & 7140 & 7850 & -1.83 & 6.91 & 0.83 & 0.43 \\
\hline $\mathrm{A} 2$ & VINT & VINTERSOL & 20 & 456 & 139 & -6.47 & 10.53 & 0.74 & 0.11 \\
\hline 01 & VINT & ERA-I & 20 & 456 & 139 & -4.29 & 9.74 & 0.72 & 0.18 \\
\hline $\mathrm{O} 2$ & VINTx2 & ERA-I & 20 & 456 & 272 & -3.18 & 8.84 & 0.75 & 0.26 \\
\hline $\mathrm{O} 3$ & GAW & ERA-I & 28 & 669 & 168 & -1.94 & 8.53 & 0.75 & 0.26 \\
\hline
\end{tabular}

assume that ERA-I sufficiently mimics the true state of the atmosphere (Dragani, 2011, has an error discussion).

Figures 1(a) and 1(b) show the different coverage of stations on the $\mathrm{NH}$ chosen for the OSSE experiments. While the original VINTERSOL station network (VINT) was kept for experiments $\mathrm{A} 2$ and $\mathrm{O} 1$, changes were made for experiments $\mathrm{O} 2$ and $\mathrm{O} 3$ to investigate the impact of sounding rates and station coverage. For experiment O3, stations were randomly chosen from the $\mathrm{NH}$ part of the original GAW network to reach a more homogeneous station coverage with respect to longitude and latitude. Additionally, the number of active stations was reduced in areas with exceptional dense coverage, e.g. continental Europe. In this way, 28 stations were finally chosen for the simulated GAW network. From inspection of Table 1, it can be found that most changes to the station coverage are due to additional stations in Russia and fewer stations in Europe and Canada. Table 3 shows the 'area affected' by both VINTERSOL and the simulated GAW network. Compared to the VINT network, the total coverage has been increased for the GAW experiment by nearly $50 \%$ and the respective mean sounding rate per station decreased from 7 to 6 launches per month. For the network VINTx2, while keeping the original VINTERSOL station layout, the number of soundings has been nearly doubled allowing a maximum of one sounding per day. Regarding the timing of simulated soundings, the initial sounding date is calculated using a random function for each station. Afterwards, a fixed time interval is used depending on the station's mean sounding rate.

\section{Set-up of the assimilation system}

For the interpolation from observation to model space (observation operators), different approaches were chosen depending on the data characteristics. For the assimilation of MIPAS level 2 observations (experiment A1), corresponding data were linearly interpolated from the neighboring model levels to the location of the observation depending on the log-pressure distance within the height range of the CTM, i.e. between 440 and $0.1 \mathrm{hPa}$. Ozone soundings, in general, cover an altitude range between surface and $5 \mathrm{hPa}$ with coverage decreasing rapidly above $10 \mathrm{hPa}$. For quality control, ozonesonde observations which differ from the model first-guess by more than 10 times the a priori observational error, are excluded from assimilation. In the case of February 2003 assimilation experiments, this results in most of sonde data below $250 \mathrm{hPa}(\approx 10 \mathrm{~km}$ altitude) being rejected. Therefore, assimilation of simulated soundings (experiments $\mathrm{O} 1, \mathrm{O} 2$ and $\mathrm{O} 3$ ) was principally limited to the altitude region between 250 and $10 \mathrm{hPa}$. Because the vertical resolution of ozonesonde observations is much better than the model's grid resolution, all ozonesonde measurements were interpolated onto the model grid before assimilation. This was done by using a moving average giving maximum weight to the observation nearest to a model level and zero weight for observations at one vertical step-size distance. With respect to the horizontal location of stations, ozonesonde observations were attributed to the nearest model grid point. This simple approach is justified by the expected but unknown drift of radiosondes (section 1).

For the simulation of VINTERSOL ozone soundings, ozone profiles were extracted from the ERA-I 1200 UTC ozone fields. To approximately match the SACADA icosahedral grid, ERA-I data were derived from the archive on a $1.5^{\circ}$ latitude-longitude grid. For soundings at a given station location, the nearest ERA-I grid point was chosen. No additional correction was applied regarding spatial or temporal mismatch between a VINTERSOL sounding and the respective ERA-I profile, i.e. soundings were assumed to be instantaneous. Note that the experiments $\mathrm{O} 1$ and A2 were meant to check these simplifications. Results are discussed in section 7.

Given that observation errors are unbiased and uncorrelated, the consistency of a priori errors can be tested according to linear estimation theory by the $\chi^{2}$ diagnostic (Appendix A gives the definition). It has been successfully used in several assimilation studies (e.g. Ménard and Chang, 2000; Chipperfield et al., 2002). We calculate mean results by accumulating over all observations for February 2003. In the case of A1, the observation errors are taken from the MIPAS level 2 data product. The minimum relative error of 5\%, used by (Schwinger and Elbern, 2010) for ozone only, is imposed for all retrieved species. Initial experiments showed that a prescribed background error of $16 \%$ results in $\chi^{2}$ mean values very close to the optimum value of 1.0 for ozone. Significantly higher $\chi^{2}$ values are found for $\mathrm{HNO}_{3}$ and $\mathrm{H}_{2} \mathrm{O}$. Further analysis showed that respective firstguess errors increase towards the model's lower boundary, resulting in higher $\chi^{2}$ values. Within the stratosphere, all assimilated species fulfil the $\chi^{2}$ criterion within a $30 \%$ range.

Because the observation characteristics differ between satellite and ground-based data, we follow the Desroziers 

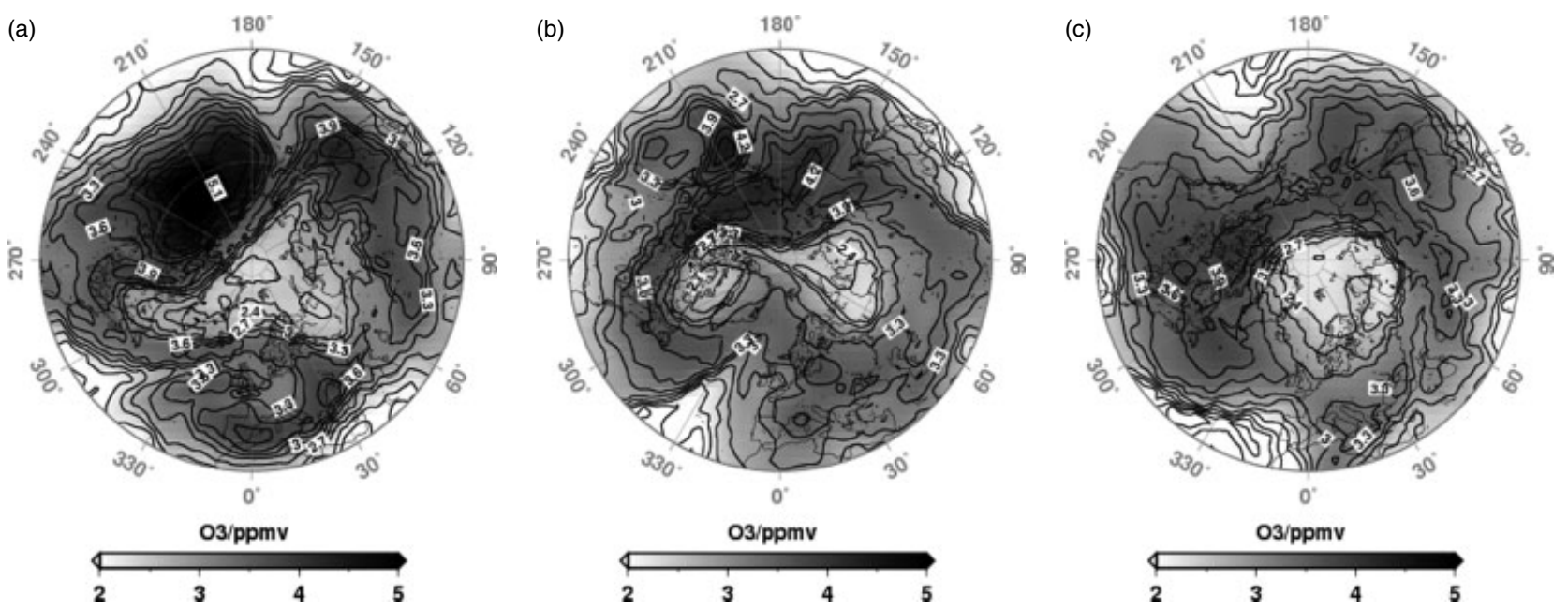

Figure 2. Ozone mixing ratios (ppmv) at $20 \mathrm{~km}$ altitude for three days in February 2003 from ERA-I reanalysis valid for 1200 UTC: (a) 1 February, (b) 15 February and (c) 28 February.

approach (Desrozier et al., 2005) to derive improved a priori errors for the assimilation of ozonesonde data. This approach allows for the a posteriori calculation of 'diagnosed' background and observation errors based on linear estimation theory using simple error diagnostics in observation space. If the a priori covariances are specified correctly, they equal their diagnosed counterparts, which allows for the identification of an optimal or near-optimal covariance setting as described in Appendix A. Since the Desroziers approach alone may provide ambiguous results (Schwinger and Elbern, 2010), the method was applied in combination with the $\chi^{2}$ diagnostic. Therefore, a set of tuning experiments with varying a priori errors was performed for all OSSEs. Table 5 shows the final tuning results (Appendix B gives details). Note that a priori errors derived for the assimilation of simulated ozone soundings (experiments $\mathrm{O} 1, \mathrm{O} 2$ and $\mathrm{O} 3$ ) are smaller than respective results for the VINTERSOL experiment A2. This is expected due to comparable spatial resolution of the SACADA and IFS-I ozone fields, i.e. the underlying grids show comparable truncation errors. The horizontal and vertical length-scales for the background-error correlation matrix were fixed for this study at values of $600 \mathrm{~km}$ and $3 \mathrm{~km}$, respectively, as recommended by (Schwinger and Elbern, 2010).

\section{The Northern Hemispheric stratosphere during February 2003}

The stratospheric winter of 2002/2003 started out exceptionally cold with a strong minor warming in February. (Günther et al., 2008) give a detailed discussion of the stratospheric meteorological evolution. After a period with very low temperatures during December 2002 and early January 2003 inside the polar vortex, the vortex was increasingly distorted, broke up and re-merged several times, first in mid-January and again mid-February. A strong vortex is in general characterized by high values of Ertel's potential vorticity (EPV), low $\mathrm{CH}_{4}$ concentrations and low temperatures within the vortex interior. The vortex distortion and split-up was also visible in the lower-stratospheric geopotential field, which showed a strong increase of the planetary zonal wavenumber two. The break-up led to strong heat and mass fluxes into high latitudes. Material mixing occurred not only over the vortex edges but also by engulfment due to re-merging of the vortex remnants (Günther et al., 2008). Thus higher $\mathrm{CH}_{4}$ concentrations can be expected within the reformed vortex at the end of February 2003 (next section). Just before the vortex split, minimum temperatures in early February fell again below $195 \mathrm{~K}$ near $20 \mathrm{~km}$ altitude, while two strong warming pulses accompanied the vortex break-up.

To discuss the ozone variability during February, we here refer to the ERA-I reanalysis. Figure 2 shows the ERA-I ozone distribution at $20 \mathrm{~km}$ altitude for three days in February 2003, i.e. before, during and after the vortex split. In general they correspond well to ozone column observations by satellites, as is evident, for example, in maps based on the ERS2/GOME (e.g. http://www.temis.nl/protocols). The vortex split led to two areas with low ozone clearly visible on 15 February. While slowly moving southward, the corresponding dipole structure was observable until late February bringing low-ozone air over Canada and Siberia. Irreversible mixing of low-ozone air into middle latitudes was limited. The two vortices reunified until the end of February with the centre of low ozone again located over Svalbard.

Stratospheric polar ozone loss in 2002/2003 has been analysed in detail by a number of authors using different methods. For example, (Feng et al., 2005) used 3D model calculations to derive vertically resolved loss rates. They compared model results to M55 Geophysica aircraft and sonde ozone observations. With respect to 1 December 2002 , they found maximum losses of $30 \%$ over the station Ny-Ålesund at $20 \mathrm{~km}$ altitude. Depletion started mainly in January and stopped only temporarily, when stratospheric temperatures rapidly increased due to the minor warming event. Christensen et al. (2005) derived the vortex-averaged chemical ozone loss based on ozone soundings and with respect to transport effects and diabatic descent. Apart from the vortex split in mid-February, they found no significant transport of ozone into the vortex collar at the $475 \mathrm{~K}$ level $(\approx 19 \mathrm{~km}$ altitude $)$. Their results compare well with the MATCH approach used by (Streibel et al., 2006). The latter authors calculated maximum daily depletion rates within

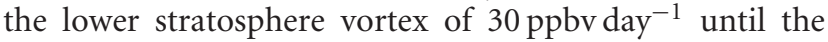
middle of February. (Tilmes et al., 2003) report maximum depletion inside the vortex core for the end of February using tracer-tracer correlation. With respect to chlorine activation via PSCs, model studies also reveal that for February 2003 

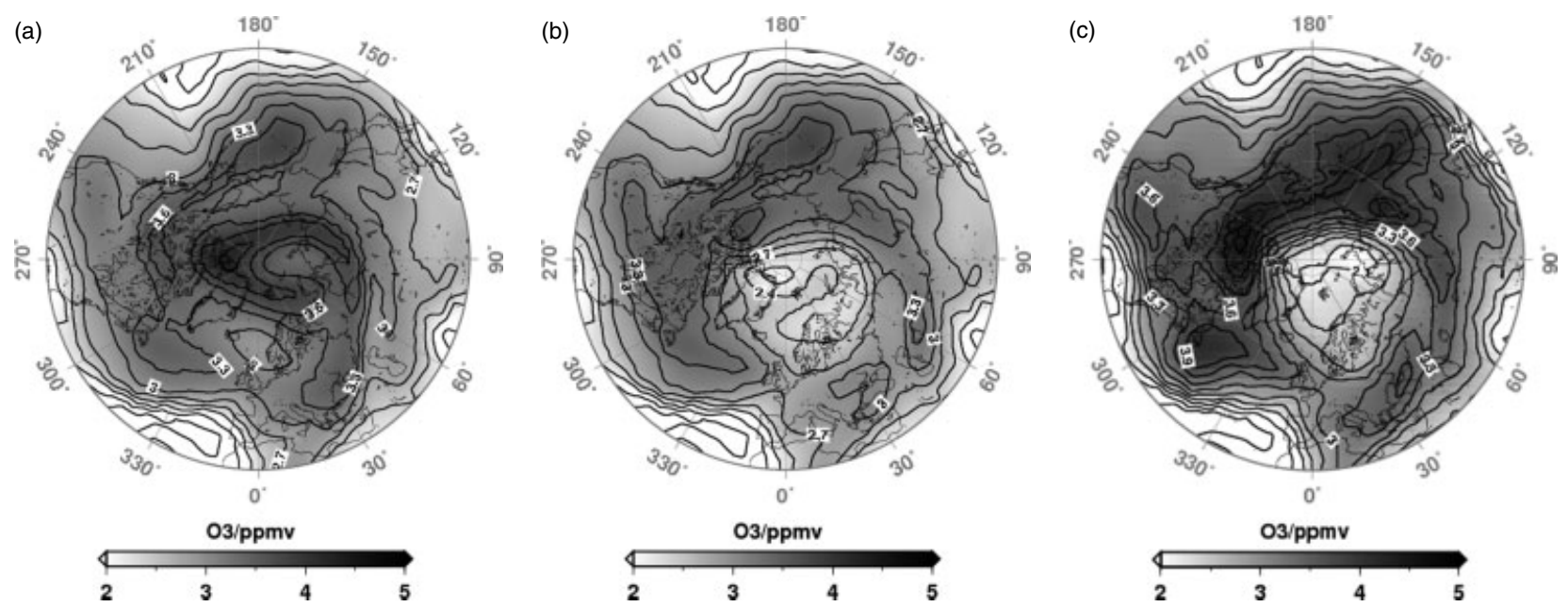

Figure 3. As Figure 2, but for 28 February 2003 for (a) the free-run experiment FR, (b) experiment A2 assimilating VINTERSOL ozonesoundings and (c) experiment A1 based on MIPAS data.

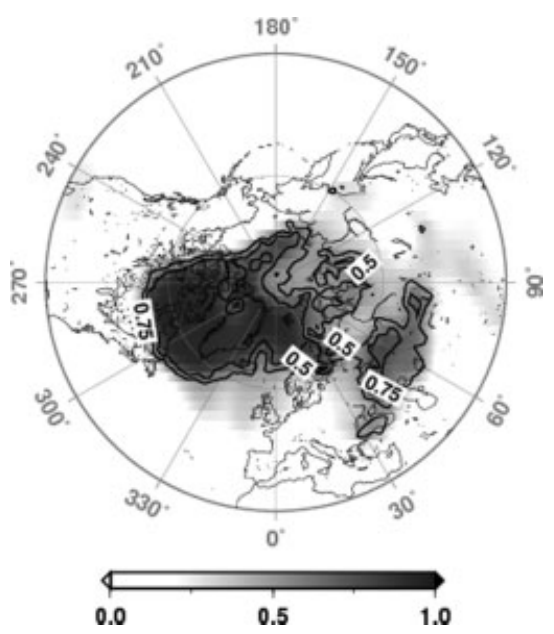

Figure 4. The Pearson's pattern correlation difference for February 2003 showing the overall improvement by experiment A2 compared to FR of ozone mixing ratios at $20 \mathrm{~km}$ altitude due to ozonesonde assimilation. Contour lines show significant correlation changes only.

(e.g. Feng et al., 2005; Goutail et al., 2005) excessive chemical ozone depletion was limited to a few days in early and late February.

\section{Discussion of results}

\subsection{Synoptic situation}

Before discussing OSSE results, we start with a comparison of results from assimilation experiments A1 (MIPAS assimilation) and A2 (VINTERSOL assimilation) with respect to the ERA-I ozone distribution. Experiments A1 and $\mathrm{A} 2$ will be used as the reference for the OSSEs O1, O2 and $\mathrm{O} 3$. Figures $2(\mathrm{a}, \mathrm{b}, \mathrm{c})$ show the ERA-I ozone distribution at $20 \mathrm{~km}$ altitude on 1, 15 and 28 February, respectively. Figures $3(\mathrm{a}, \mathrm{b}, \mathrm{c})$ show the ozone distributions for the FR, the VINTERSOL experiment (A2) and the MIPAS-SACADA analysis (A1) for 28 February. On this date, the vortex had already recovered from the vortex split event in midFebruary (Figure 2(b)). As is evident by comparison of Figures 2(c) and 3(a), within the inner vortex area, ozone is strongly overestimated by the free run.
By comparison of ozone to EPV and $\mathrm{CH}_{4}$, the different influence of transport and chemistry can be assessed (e.g. Müller et al., 2002). We find that the model tends to overestimate ozone in areas with high EPV and low $\mathrm{CH}_{4}$, typical of conditions inside the vortex. In fact, correlation of FR with ERA-I is especially poor in these areas. As both $\mathrm{CH}_{4}$ and ozone strongly increase north of $70^{\circ} \mathrm{N}$ during February 2003 in FR, the overestimation of ozone indicates that the inner vortex air is less isolated when compared to diagnostic results based on observations (Christensen et al., 2005). Contrary to the FR, the MIPAS-SACADA analysis (A1) shows significant ozone depletion in regions defined by PVU values $>45 \mathrm{PVU}\left(1 \mathrm{PVU} \equiv 10^{-6} \mathrm{~K} \mathrm{~m}^{2} \mathrm{~kg}^{-1} \mathrm{~s}^{-1}\right)$.

As in experiment $\mathrm{A} 1$, the overestimation of ozone by the free model run, evident within the vortex on 28 February, is significantly reduced when data from ozonesondes are assimilated (experiment A2, Figures 3(b, c)). However, due to the assimilation of ozone only, the ozone- $\mathrm{CH}_{4}$ correlation is different for A2 showing higher $\mathrm{CH}_{4}$ values within the vortex. Comparison of Figures 2(b) and 4 shows that pattern correlation mostly improves over the Labrador Sea $(+80 \%)$, close to the position of the westerly vortex remnant on 15 February (see discussion in subsection 7.2). These findings hold also for experiments with simulated data, i.e. O1, O2 and O3 (not shown). After the vortex split, all OSSEs show higher minimum ozone values than A1.

During the vortex break-up, OSSEs show higher ozone concentrations over the westerly vortex remnant to the west of Greenland, while ozone over the polar region north of East Siberia, Alaska and Canada is slightly reduced (Figure 5). Although the ozone maxima seems to be partly better represented by $\mathrm{O} 3$, it is difficult to judge which experiment gives superior results by direct comparison of ozone distributions only. We therefore discuss changes to pattern correlation in the following subsection.

\subsection{Pattern correlation}

Figure 4 shows the impact of VINTERSOL ozone soundings (experiment A2) in terms of mean Pearson's pattern correlation change with respect to the FR. Figure 6 compares pattern correlation results for the OSSEs O1, O2 and O3.

We use mean Pearson's correlation (Appendix B gives the definition) for the $20 \mathrm{~km}$ model level derived for February 

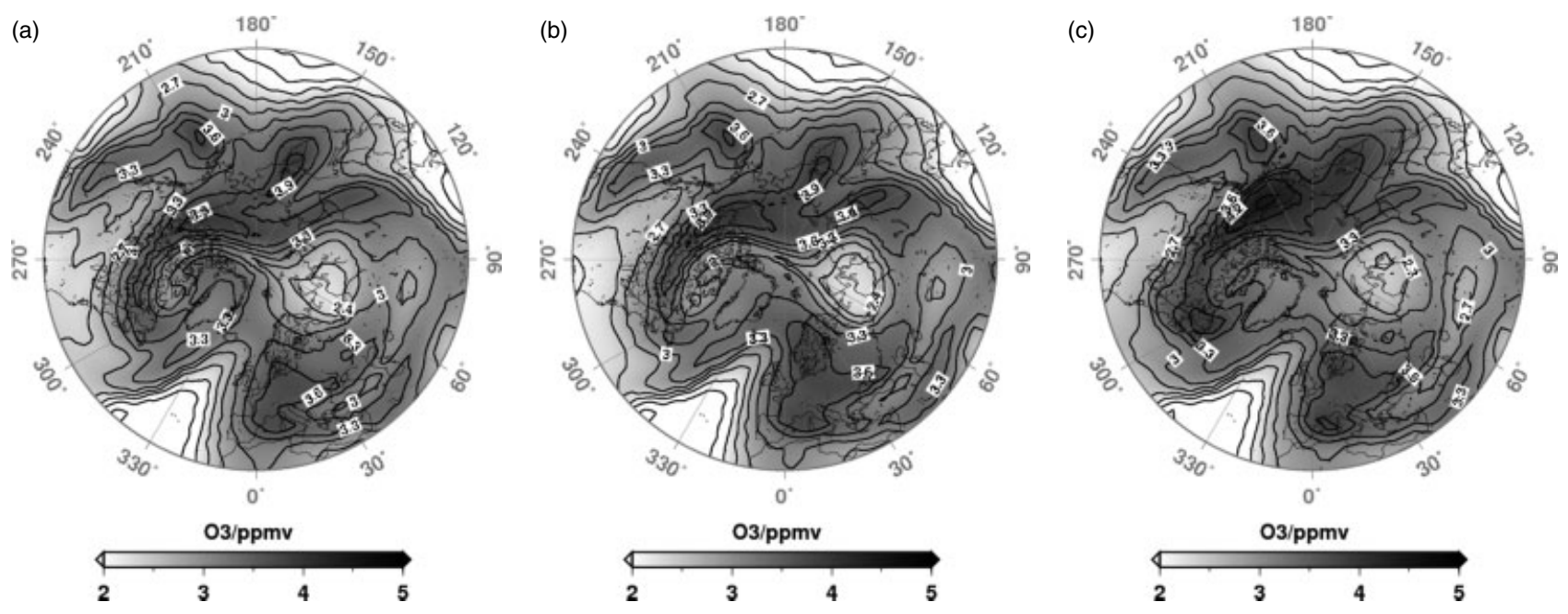

Figure 5. Ozone mixing ratios (ppmv) on the $20 \mathrm{~km}$ altitude model level for 15 February 2003: results for (a) the OSSE experiment O1 using simulated VINTERSOL soundings, (b) experiment $\mathrm{O} 2$ with doubled sounding rates and (c) experiment $\mathrm{O} 3$ using the GAW station network.
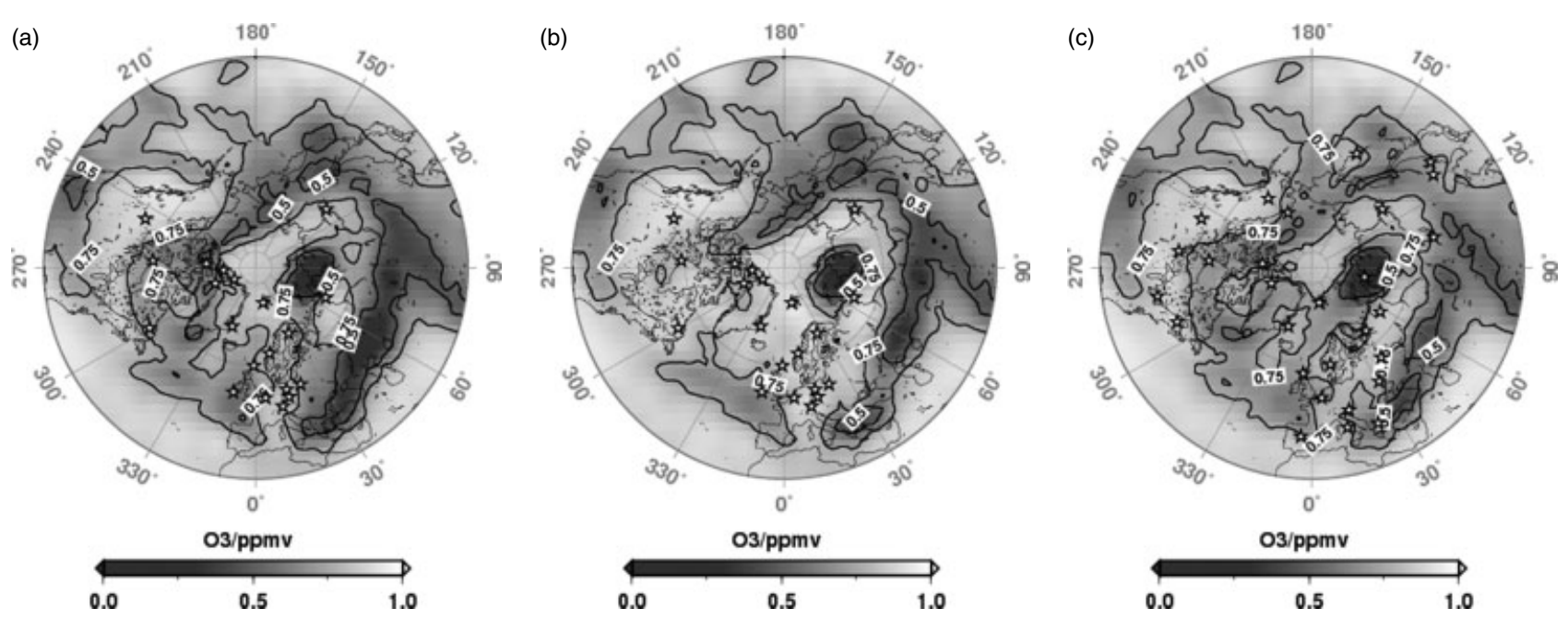

Figure 6. Pearson's pattern correlation of ozone mixing ratios at $20 \mathrm{~km}$ altitude for OSSEs covering February 2003 compared with ERA-I reanalysis. Station locations are shown as stars. (a) O1 with simulated VINTERSOL soundings, (b) O2 results using doubled sounding rates, and (c) O3 results for the GAW station network. Contour lines are drawn only above the significance level 0.32 .

2003 with respect to ERA-I to quantify the spatio-temporal performance of ozonesonde experiments. Note that here we use correlation as a relative measure between experiments based on the same reference data (ERA-I) but using different station network configurations. Results are only valid for February 2003. The absolute numbers may differ if other reference data were used. The $5 \%$ correlation significance level has been estimated to be 0.32 . Direct inspection of pattern correlation for $\mathrm{A} 2$ and $\mathrm{O} 1$ experiments shows that the spatial distributions are almost identical apart from small differences for a few regions (not shown). For example, correlation over southern Greenland is higher in the original VINTERSOL data experiment A2, while performance over the Siberian coast (east of Novaya Zemlya) is slightly better in $\mathrm{O} 1$.

Because differences in pattern correlation between A2 (VINTERSOL assimilation) and O1 (simulated ozone soundings) are generally small, we will discuss results only for O1. In general, areas with reduced pattern correlation coincide with poor station coverage, e.g. central Asia and the Bering Sea. Detailed inspection of Figure 6(a) shows that VINTERSOL station coverage is especially poor over most of Southern Europe, and is very limited north of $70^{\circ} \mathrm{N}$. Experiment $\mathrm{O} 2$ (Figure $6(\mathrm{~b})$ ), using increased sounding rates, gives the highest correlation values of all OSSEs and shows the most significant improvements over northern Canada/Greenland, southeast Europe and parts of central Asia. Results for the $\mathrm{O} 3$ experiment (Figure 6(c)), which uses a more dispersed station coverage, are mixed. While showing no improvements over northern Canada, Greenland and the Arctic Ocean, O3 performs slightly better than $\mathrm{O} 1$ over southeast Europe and central Asia.

In all OSSEs, the region with the weakest correlation can be found to the east of the island of Novaya Zemlya (Figure 6). As inspection of Figures 3(b) and 5 shows, on 15 February 2003, Novaya Zemlya lies in the region with strong ozone gradients of the westerly vortex. After the vortex split in February 2003, the easterly vortex part is firstly located over the Urals/central Siberia, moving then towards the east of Novaya Zemlya. Directly to the north of Urals/Novaya Zemlya, observational coverage is poor in all experiments. Under the conditions of the February 2003 vortex split, even the nearby station Dikson Island in experiment $\mathrm{O} 3$ is not able to sufficiently constrain the analyses. On the contrary, results indicate that, 
depending on the large-scale flow pattern, local correlations can be influenced by remote soundings at upstream stations.

\subsection{Mean scoring results}

Table 3 gives an overview of mean February scoring results for $20 \mathrm{~km}$ altitude ozone for all experiments of this study by comparison to the ERA-I reanalysis.

In general the accuracy of MIPAS-SACADA results (A1) compares well with other assimilation studies based on MIPAS observations (Baier et al., 2005; Errera et al., 2008; Schwinger and Elbern, 2010). Mean bias and statistical errors with respect to Halogen Occultation Experiment (HALOE) observations (Brühl et al., 1996) are found to be at the $3 \%$ and $9 \%$ level, respectively. These errors are well within the known error range of MIPAS and HALOE for the lower stratosphere (Brühl et al., 1996; Bracher et al., 2004). While the FR shows higher statistical deviations, the bias is significantly smaller than A1, indicating systematic differences between MIPAS and HALOE.

All experiments show a significant increase of the mean Pearson correlation and the mean relative skill score with respect to the FR. As expected, the MIPASSACADA experiment A1 results in the highest mean score. Experiments based on the original VINTERSOL network, i.e. A2 and O1, show relative skill scores of 0.11 and 0.18 , respectively. By increasing sounding rates or using a better distributed station network, both $\mathrm{O} 2$ and $\mathrm{O} 3$ experiments show a strong increase of the relative skill score to 0.26 compared to the FR. With respect to bias and statistical errors, $\mathrm{O} 3$ is superior to $\mathrm{O} 2$, showing a reduction of $50 \%$ and $10 \%$ of the normalized mean bias (NMB) and fractional gross error (FGE), respectively.

Our initial assumption that the ERA-I reanalysis can be used for OSSEs to simulate ozonesonde observations is vindicated in general by further inspection of scoring data for experiments A2 and O1. Fractional gross error and mean Pearson correlation differences are small (Table 3 ). On the other hand, the normalized mean bias for experiment A2 is considerably higher than $\mathrm{O} 1$ results. Detailed analysis of model observation minus first-guess residuals at $20 \mathrm{~km}$ shows that assimilation of VINTERSOL ozonesonde data tends to increase the negative ozone bias of the FR model, while the assimilation of ERA-I ozone decreases this bias, thus leading to overall smaller NMB values. The generally smaller mean errors and higher skill scores for experiments with simulated VINTERSOL soundings may be explained by better representativeness of ERA-I reanalysis data and smaller bias.

\section{Summary and recommendations}

We have presented an observing system simulation study using the $4 \mathrm{D}$-Var assimilation system SACADA to investigate the impact of ozonesonde observations during a simulated satellite data gap in February 2003. Results were compared to a MIPAS-SACADA reference experiment and independent ERA-Interim reanalysis data. We used the $20 \mathrm{~km}$ altitude level as a proxy for model performance in the lower winter stratosphere. We showed that the assimilation of VINTERSOL ozonesonde observations has a significant positive impact on the model's analysis skill and that, by simulating profile soundings based on the ERA-Interim reanalysis, the influence of different station networks can be assessed. In February 2003, ozone variability at high latitudes was strongly influenced by the mid-February vortex split. Analysis of the $\mathrm{O}_{3} / \mathrm{CH}_{4}$ ratio indicates that, without assimilation, the modelled chemical ozone loss is masked by positive mass flux into the vortex remnants. When VINTERSOL ozonesonde data are assimilated, the mean relative skill score at $20 \mathrm{~km}$ altitude reaches 0.11 for all latitudes north of $30^{\circ} \mathrm{N}$ compared to a FR. The most significant improvement $(+80 \%)$, in terms of linear pattern correlation, is found over the Labrador Sea, where the westerly vortex part was located after the split event. OSSE results with simulated ozonesonde networks show that increased sounding rates or improved station coverage increases the skill score by nearly $45 \%$, compared to the VINTERSOL configuration. Thus, a smaller sounding rate can be completely compensated by a more dispersed station coverage. In our case, a GAW-based network with 28 stations and approximately three soundings fortnightly per site is clearly superior, taking into account the gain in skill and improvement of error scores. It is beyond the scope of this article to derive the optimum station network layout, as this will strongly depend on the prevailing dynamic situation. Although our results indicate that the analyzed ozone field could be further improved by soundings in regions with increased ozone variability, this has to be further investigated by experiments with other more extended time periods. In a forthcoming article, we will therefore extend the database and analyze the impact of stations in areas with transient atmospheric variability. With respect to chemical ozone depletion, our results are masked by the vortex split event. Future studies should address less-distorted conditions with strong chemical depletion, e.g. due to local PSC activity.

In summary, our results demonstrate that, at least for the time period of one month, ozone soundings could be beneficial for chemical data assimilation systems in the event of satellite instrument failure and subsequent data gaps. Though we only investigated results for a limited time period and a single altitude layer, it can be expected that profile data has a significant positive impact on analyses for other time periods throughout the lower stratosphere. By probing the prospects for ozonesonde observations, this study strongly supports the idea of an integrated Global Observing System (GCOS, 2009) by optimally taking into account ground-based and satellite data.

\section{Appendices}

\section{A. Tuning of a priori errors}

A set of tuning experiments was performed for all OSSE ozonesonde experiments $\mathrm{O} 1, \mathrm{O} 2$ and $\mathrm{O} 3$ with varying a priori errors. Due to the sparseness of observations, we calculated monthly mean results by summing over all days in February 2003. Starting with the settings for A1, $\chi^{2}$ numbers were generally found too low, and consequently, background and observational a priori errors were alternately reduced by successive runs to better match the diagnostic quantities. A two-parameter mapping of diagnosed $\sigma_{o}$ and $\chi^{2}$ tuning-results for experiment $\mathrm{O} 1$ 
Table A.1. $\chi^{2}$ diagnostic results and a priori errors used for a given ozonesonde experiment (Appendix A gives details). The last two columns show respective diagnostic a priori errors derived following Desrozier $e t$ al. (2005).

\begin{tabular}{lccccc}
\hline Exp. & $\chi^{2}$ & $\sigma_{b}(\%)$ & $\sigma_{o}(\%)$ & $\widetilde{\sigma}_{b}(\%)$ & $\widetilde{\sigma}_{o}(\%)$ \\
\hline A2 & 1.00 & 13.0 & 5.0 & 11.5 & 4.8 \\
O1 & 0.98 & 11.0 & 3.0 & 8.9 & 2.8 \\
O2 & 0.97 & 10.0 & 3.0 & 7.7 & 2.7 \\
O3 & 1.02 & 10.0 & 2.5 & 7.6 & 2.3 \\
\hline
\end{tabular}

indicates that a priori error settings exist where both the ratio of diagnosed to a priori observation error and the $\chi^{2}$ value approximately equal one. However, it is found that the diagnosed background error stays persistently smaller than the applied a priori background error for all $a$ priori error settings tested. This result is consistent with the findings of (Schwinger and Elbern, 2010) who showed that the Desroziers diagnostic tends to underestimate the background error in a $4 \mathrm{D}-\mathrm{Var}$ context. Further, a fully consistent covariance specification is unlikely to be attainable with a simple global relative error specification as applied in this study. Therefore, tuning results were accepted as near-optimal when matching the respective diagnostic values within $20 \%$ for the background error and $10 \%$ for the observational a priori error. Table A.1 shows the final a priori error settings used for the OSSE experiments.

\section{B. Definition of scoring parameters}

Table B.1 shows an overview of scoring metrics used for the evaluation of assimilation results given in this study. In the following, $M$ is the number of observations, while $N$ denotes the number of model grid points on the $20 \mathrm{~km}$ model level for all latitudes north of $30^{\circ} \mathrm{N}$ and all days in February 2003. Formulae 1, 2 and 3 show the calculation of error residuals in observation space at measurement time, i.e. within the model's time step of $10 \mathrm{~min}$. Variables $f_{i}, o_{i}$ and $a_{i}$ denote corresponding first-guess, observational and analysis values. Formulae 4 and 5 show how scoring metrics are calculated in model space for 1200 UTC based on experimental results $e_{i}$ with respect to the reference values $r_{i}$ of ERA-I. Note that relative bias and statistical errors are calculated using the sum of value pairs in the denominator to reduce the influence of outliers. Formula 6 defines the relative skill score using the ratio of experiments $E_{I}=\mathrm{A} 1$, $\mathrm{A} 2, \mathrm{O} 1, \mathrm{O} 2$ and $\mathrm{O} 3$ to the FR. Pearson's correlation is defined by formula 7 with $\sigma_{E_{I}}$ and $\sigma_{R}$ representing the variance sigma values derived for all experiments $E_{I}$ and ERA-I as reference dataset $R$ at each grid point by summing over all days. The $5 \%$ correlation significance level of 0.32 was calculated using the Student $t$ distribution based on 28 value pairs. The mean Pearson's correlation (used in Table 3 ) is calculated by summing over all individual model grid points. Formula 8 shows the derivation of $\chi^{2}$ diagnostic numbers based on the first-guess minus observation residuals and a priori errors for model background and observations. Diagnostic a priori errors $\widetilde{\sigma}_{b}$ and $\widetilde{\sigma}_{o}$ are calculated by summing over all error residuals in observation space (formulae 9 and 10, respectively) following (Desrozier et al., 2005).

\section{Acknowledgement}

We are grateful to all data providers and collaborators. We especially thank the Norwegian Institute for Air Research (NILU) for providing the VINTERSOL ozonesonde data. The European Space Agency (ESA) is acknowledged for providing MIPAS offline level 2 data funded within the framework of the ESA-AO project EVIVA (ENVISAT Value adding Atmosphere). Operational processing of ENVISAT data is carried out by the German Aerospace Center (DLR) on behalf of ESA. We thank ECMWF for access to daily meteorological analyses and ERA-I data. We are grateful to the National Center for Atmospheric Research (NCAR) for the SOCRATES 10-year climatology. The National Aeronautic and Space Agency (NASA) provides HALOE version 19 observations via the Goddard Earth Sciences Data Center. This study was partly funded by EC GMES FP7 project MACC (Monitoring of the Atmosphere, Climate and Chemistry) and the ENVISAT VA-Atmosphere project of DLR. We would finally thank Anne Smith from NCAR for providing code for the new SACADA photolysis scheme. The SACADA assimilation system has been developed within the federal German AFO2000 project SACADA.

Table B.1. Formulae for observation space error diagnostics, model-based scoring metrics and diagnostic a priori error calculation used in this study. Appendix B gives details.

\begin{tabular}{lcc}
\hline Error metric & Abbreviation & \multicolumn{1}{l}{ Formula } \\
\hline First-guess minus observation & FMO & $f_{i}-o_{i}$ \\
Analysis minus first-guess & AMF & $a_{i}-f_{i}$ \\
Observation minus analysis & OMA & $o_{i}-a_{i}$ \\
Fractional gross error & FGE & $\frac{2}{N} \sum\left|e_{i}-r_{i}\right| /\left|e_{i}+r_{i}\right|$ \\
Normalized mean bias & NMB & $\frac{2}{N} \sum\left(e_{i}-r_{i}\right) /\left(e_{i}+r_{i}\right)$ \\
Relative skill score & RSS & $1-F G E / F G E_{\mathrm{FR}}$ \\
Pearson's correlation & PC & $\operatorname{cov}\left(E_{I}, R\right) /\left(\sigma_{E_{I}} \cdot \sigma_{R}\right)$ \\
Chi-squared diagnostic & $\chi^{2}$ & $\frac{1}{M} \sum F M O_{i}^{2} /\left(\sigma_{b i}^{2}+\sigma_{o i}^{2}\right)$ \\
Diagnosed background error & $\tilde{\sigma}_{b}$ & $\frac{1}{M} \sum A M F_{i} \cdot F M O_{i}$ \\
Diagnosed observational error & $\tilde{\sigma}_{o}$ & $\frac{1}{M} \sum O M A_{i} \cdot F M O_{i}$ \\
\hline
\end{tabular}




\section{References}

Baier F, Erbertseder T, Morgenstern O, Bittner M, Brasseur G. 2004. Assimilation of MIPAS observations using a three-dimensional global chemistry-transport model. Q. J. R. Meteorol. Soc. 131: 3529-3542.

Borchi F, Pommereau JP. 2007. Evaluation of ozonesondes, HALOE, SAGE II and III, Odin- OSIRIS and -SMR, and ENVISAT-GOMOS, -SCIAMACHY and -MIPAS ozone profiles in the Tropics from SAOZ long-duration balloon measurements in 2003 and 2004. Atmos. Chem. Phys. 7: 2671-2690.

Brühl C, Drayson SR, Russell JM III, Crutzen PJ, McInerney JM, Purcell PN, Claude H, Gernandt H, McGee TJ, McDermid IS, Gunson MR. 1996. Halogen Occultation Experiment ozone channel validation. J. Geophys. Res. 101: (D6) 10 217-10 240.

Bracher A, Bramstedt K, Sinnhuber M, Weber M, Burrows JP. 2004. 'Validation of MIPAS O3, NO2, $\mathrm{H} 2 \mathrm{O}$ and $\mathrm{CH} 4$ profiles (v4.61) with collocated measurements of HALOE and SAGE II'. In Proceedings of the Second Workshop on the atmospheric chemistry validation of ENVISAT (ACVE-2), Frascati, Italy. Publication SP-562. ESA: Paris.

Cariolle D, Déqueé M. 1986. Southern hemisphere medium-scale waves and total ozone disturbances in a spectral general circulation model. J. Geophys. Res. 91: 10 825-10 846.

Carli B, Alpaslan D, Carlotti M, Castelli E, Ceccherini S, Dinelli BM, Dudhia A, Flaud JM, Höpfner M, Jay V, Magnani L, Oelhaf $H$, Payne V, Piccolo C, Prosperi M, Raspollini P, Ridolfi M, Remedios J, Spang R. 2004. First results from MIPAS/ENVISAT with operational Level 2 code. Adv. Space Res. 33: (7) 1012-1019, DOI: 10.1016/S02731177(03)00 584-2.

Charlton AJ, O'Neill A, Lahoz WA, Massacand AC. 2004. Sensitivity of tropospheric forecasts to stratospheric initial conditions. Q. J. R. Meteorol. Soc. 130: 1771-1792.

Chipperfield MP, Khattatov BV, Lary DJ. 2002. Sequential assimilation of stratospheric chemical observations in a three-dimensional model. J. Geophys. Res. 107: (D21) 4585, DOI: 10.1029/2002JD002110

Christensen T, Knudsen BM, Streibel M, Andersen SB, Benesova A, Braathen G, Claude H, Davies J, De Backer H, Dier H, Dorokhov V, Gerding M, Gil M, Henchoz B, Kelder H, Kivi R, Kyrö E, Litynska Z, Moore D, Peters G, Skrivankova P, Stübi R, Turunen T, Vaughan G, Viatte P, Vik AF, von der Gathen P, Zaitcev I. 2005. Vortex-averaged Arctic ozone depletion in the winter 2002/2003. Atmos. Chem. Phys. 5: 131-138, DOI: 10.5194/acp-5-131-2005

Cortesi U, Lambert JC, De Clercq C, Bianchini G, Blumenstock T, Bracher A, Castelli E, Catoire V, Chance KV, De Mazire M, Demoulin P, Godin-Beekmann S, Jones N, Jucks K, Keim C, Kerzenmacher T, Kuellmann H, Kuttippurath J, Iarlori M, Liu GY, Liu Y, McDermid IS, Meijer YJ, Mencaraglia F, Mikuteit S, Oelhaf H, Piccolo C, Pirre M, Raspollini P, Ravegnani F, Reburn WJ, Redaelli G, Remedios JJ, Sembhi H, Smale D, Steck T, Taddei A, Varotsos C, Vigouroux C, Waterfall A, Wetzel G, Wood S. 2007. Geophysical validation of MIPAS-ENVISAT operational ozone data. Atmos. Chem. Phys. 7: 4807-4867, DOI: 10.5194/acp-7-4807-2007

Damski J, Thölix L, Backmann L, Taalas P, Kulmala M. 2007. FinROSE - middle atmospheric chemistry transport model. Boreal Env. Res. 12: 535-550.

Dee DP, Uppala SM, Simmons AJ, Berrisford P, Poli P, Kobayashi S, Andrae U, Balmaseda MA, Balsamo G, Bauer P, Bechtold P, Beljaars ACM, van de Berg L, Bidlot J, Bormann N, Delsol C, Dragani R, Fuentes M, Geer AJ, Haimberger L, Healy SB, Hersbach H, Hólm EV, Isaksen L, Kållberg P, Köhler M, Matricardi M, McNally AP, Monge-Sanz BM, Morcrette J-J, Park B-K, Peubey C, de Rosnay P, Tavolato C, Thépaut J-N, Vitart F. 2011. The ERA-Interim reanalysis: configuration and performance of the data assimilation system. Q. J. R. Meteorol. Soc. 137: 553-597.

Deniel C, Dalaudier F, Chassefiere E, Bevilacqua RM, Shettle EP, Hoppel KW, Hornstein JS, Lumpe JD, Rusch DW, Randall CE. 1997. A comparative study of POAM II and electrochemical concentration cell ozonesonde measurements obtained over northern Europe. J. Geophys. Res. 102: (D19) 23 629-23 642, DOI: 10.1029/97JD01665

Desroziers G, Berre L, Chapnik B, Poli P. 2005. Diagnosis of observation, background and analysis error statistics in observation space. Q. J. R. Meteorol. Soc. 131: 3385-3396.

Dethof A, Hólm EV. 2004. Ozone assimilation in the ERA-40 reanalysis project. Q. J. R. Meteorol. Soc. 130: 2851-2872.

Dragani R. 2010. 'On the quality of the ERA-Interim ozone reanalyses, Part I: comparisons with in situ measurements'. ERA report series, No. 2. ECMWF: Reading, UK.

Dragani R. 2011. On the quality of the ERA-Interim ozone reanalyses: comparisons with satellite data. Q. J. R. Meteorol. Soc. 137: 1312-1326.
Elbern H, Schwinger J, Botchorishvili R. 2010. Chemical state estimation for the middle atmosphere by four-dimensional variational data assimilation: System configuration. J. Geophys. Res. 115: (D06302) DOI: 10.1029/2009JD011953

Erbertseder T, Baier F, Errera Q, Viscardy S, Schwinger J, Elbern H. 2007. 'The PROMOTE Ozone Profile Service - Long-term 3D ozone reanalysis of ERS-2 and ENIVSAT datasets'. In Proceedings of the ESA ENVISAT Symposium, 23-27 April 2007, Montreux, Switzerland. Publication SP-636, ESA: Paris.

Errera Q, Fonteyn D. 2001. Four-dimensional variational chemical assimilation of CRISTA stratospheric measurements. J. Geophys. Res. 106: (D11) 12 253-12 265, DOI: 10.1029/2001JD900010

Errera Q, Daerden F, Chabrillat S, Lambert JC, Lahoz WA, Viscardy S, Bonjean S, Fonteyn D. 2008. 4D-Var assimilation of MIPAS chemical observations: ozone and nitrogen dioxide analyses. Atmos. Chem. Phys. 8: 6169-6187, DOI: 10.5194/acp-8-6169-2008

Eskes H, van Velthoven P, Valks P, Kelder H. 2003. Assimilation of GOME total ozone satellite observations in a three-dimensional tracer transport model. Q. J. R. Meteorol. Soc. 129: 1663-1681.

Eyring V, Harris NRP, Rex M, Shepherd TG, Fahey DW, Amanatidis GT, Austin J, Chipperfield MP, Dameris M, Forster PM de F, Gettelman A, Graf HF, Nagashima T, Newman PA, Pawson S, Prather MJ, Pyle JA, Salawitch RJ, Santer BD, Waugh DW. 2005. A strategy for processoriented validation of coupled chemistry-climate models. Bull. Amer. Meteorol. Soc. 86: 1117-1133.

Feng W, Chipperfield MP, Davies S, Sen B, Toon G, Blavier JF, Webster CR, Volk CM, Ulanovsky A, Ravegnani F, von der Gathen P, Jost H, Richard EC, Claude H. 2005. Three-dimensional model study of the Arctic ozone loss in 2002/2003 and comparison with 1999/2000 and 2003/2004. Atmos. Chem. Phys. 5: 139-152, DOI: 10.5194/acp-5-139-2005

Fischer H, Oelhaf H. 1996. Remote sensing of vertical profiles of atmospheric trace constituents with MIPAS limb-emission spectra. Appl. Opt. 35: 2787-2796.

GCOS. 2009. Progress Report on the Implementation of the Global Observing System for Climate in Support of the UNFCCC 2004-2008. GCOS-129 (WMO/TD No. 1489; GOOS-173; GTOS-70) WMO: Geneva, Switzerland.

Geer AJ, Lahoz WA, Bekki S, Bormann N, Errera Q, Eskes HJ, Fonteyn D, Jackson DR, Juckes MN, Massart S, Peuch V-H, Rharmili S, Segers A. 2006. The ASSET intercomparison of ozone analyses: method and first results. Atmos. Chem. Phys. Discuss. 6: 4495-4577, DOI: 10.5194/acpd-6-4495-2006

Goutail F, Pommereau JP, Lefèvre F, van Roozendael M, Andersen SB, Kåstad Høoiskar B-A, Dorokhov V, Kyrö E, Chipperfield MP, Feng W. 2005. Early unusual ozone loss during the Arctic winter 2002/2003 compared to other winters. Atmos. Chem. Phys. 5: 665-677, DOI: 10.5194/acp-5-665-2005

Günther G, Müller R, von Hobe M, Stroh F, Konopka P, Volk CM. 2008. Quantification of transport across the boundary of the lower stratospheric vortex during Arctic winter 2002/2003. Atmos. Chem. Phys. 8: 3655-3670, DOI: 10.5194/acp-8-3655-2008

Harris N, Amanatidis G. 2003. 'VINTERSOL - A new European field campaign'. In SPARC Newsletter 20. WCRP Geneva, Switzerland.

Kerridge BJ, Reburn WJ, Jay VL, Siddans R, Latter B, Stiller G, Bréon FM, Verdes C, De Maziere M, Prunet P, Clerbaux C, Jongma RT, Bovensmann H, Remedios J, Lautié N. 2005. Assessment of existing and planned atmospheric sounding missions and networks. Report for WP2200 of ESA CAPACITY Study, ESA Study Contract no. 17 $237 / 03 / \mathrm{NL} / \mathrm{GS}$.

Kuttippurath J, Kleinbühl A, Sinnhuber M, Bremer H, Källmann H, Notholt J, Godin-Beekmann S, Tripathi O, Nikulin G. 2011. Arctic ozone depletion in 2002-2003 measured by ASUR and comparison with POAM observations. J. Geophys. Res. 116: D22305, DOI: 10.1029/2011JD016020

Levelt PF, Khattatov BV, Gille JC, Brasseur GP, Tie XX, Waters JW. 1998. Assimilation of MLS ozone measurements in the global threedimensional chemistry transport model ROSE. J. Geophys. Res. 25: (24) 4493-4496, DOI: 10.1029/1998GL900152

Lahoz WA, Brugge R, Jackson DR, Migliorini S, Swinbank R, Lary D, Lee A. 2005. An observing system experiment to evaluate the scientific merit of wind and ozone measurements from the future SWIFT instrument. Q. J. R. Meteorol. Soc. 131: 503-523.

Lahoz WA, Errera Q, Swinbank R, Fonteyn D. 2007. Data assimilation of stratospheric constituents: A review. Atmos. Chem. Phys. 7: 5745-5773, DOI: 10.5194/acp-7-5745-2007

Masutani M, Schlatter T, Errico R, Stoffelen A, Andersson E, Lahoz W, Woollen JS, Emmitt GD, Riishojgaard LP, Lord SJ. 2010. Observing 
System Simulation Experiments. In Data Assimilation - Making Sense of Observations. Lahoz W, Khattatov B, Menard R (eds). SpringerVerlag Berlin. 647-680, DOI: 10.1007/978-3-540-74 730-1

Majewski D, Liermann D, Prohl P, Ritter B, Buchhold M, Hanisch T, Paul G, Wergen W, Baumgardner J. 2001. The operational global icosahedral-hexagonal gridpoint model GME: Description and highresolution tests. Mon. Weather Rev. 130: 319-338.

Meijer YJ, Swart DPJ, Koelemeijer R, Allaart M, Andersen S. 2004. Poleto-pole validation of ENVISAT GOMOS ozone profiles using data from ground-based and balloon-sonde measurements. J. Geophys. Res. 109: (D23305) DOI: 10.1029/2004JD004834

Ménard R, Chang LP. 2000. Assimilation of stratospheric chemical tracer observations using a Kalman filter. Part II: $\chi^{2}$ validation results and analysis of variance and correlation dynamics. Mon. Weather Rev. 128: $2672-2686$.

Müller R, Tilmes S, Grooss J-U, McKenna DS, Müller M, Schmidt U, Toon GC, Stachnik RA, Margitan JJ, Elkins JW, Arvelius J, Russell JM III. 2002. Chlorine activation and chemical ozone loss deduced from HALOE and balloon measurements in the Arctic during the winter of 1999-2000. J. Geophys. Res. 107: (8302) DOI: 10.1029/2001JD001423

Nassar R, Logan JA, Worden HM, Megretskaia IA, Bowman KW, Osterman GB, Thompson AM, Tarasick DW, Austin S, Claude H, Dubey MK, Hocking WK, Johnson BJ, Joseph E, Merrill J, Morris JA, Newchurch M, Oltmans SJ, Posny F, Schmidlin FJ, Vömel H, Whiteman DN, Witte JC. 2008. Validation of Tropospheric Emission Spectrometer (TES) nadir ozone profiles using ozonesonde measurements. J. Geophys. Res. 113: (D15S17) DOI: 10.1029/2007JD008819

Peuch A, Thépaut J-N, Pailleux J. 2000. Dynamical impact of total-ozone observations in a four-dimensional variational assimilation. Q. J. $R$ Meteorol. Soc. 126: 1641-1659.

Schwinger J, Elbern H. 2010. Chemical state estimation for the middle atmosphere by four-dimensional variational data assimilation: aposteriori validation of error statistics in observation space. J. Geophys. Res. 115: (D18307) DOI: 10.1029/2009JD013115

Smit HGJ, Straeter W, Johnson BJ, Oltmans SJ, Davies J, Tarasick DW, Hoegger B, Stubi R, Schmidlin FJ, Northam T, Thompson AM, Witte JC, Boyd I, Posny F. 2007. Assessment of the performance of ECC-ozonesondes under quasi-flight conditions in the environmental simulation chamber: Insights from the Juelich Ozonesonde Intercomparison Experiment (JOSIE). J. Geophys. Res. 112: (D19306) DOI: 10.1029/2006JD007308

Stiller GP, von Clarmann T, Funke B, Glatthor N, Hase F, Höpfner M, Linde A. 2002. Sensitivity of trace gas abundances retrievals from infrared limb emission spectra to simplifying approximations in radiative transfer modelling. J. Quant. Spectrosc. Radiat. Transfer 72: 249-280.

Stiller GP, Kiefer M, Eckert E, von Clarmann T, Kellmann S, GarcaComas M, Funke B, Leblanc T, Fetzer E, Froidevaux L, Gomez M, Hall E, Hurst D, Jordan A, Kmpfer N, Lambert A, McDermid IS, McGee T, Miloshevich L, Nedoluha G, Read W, Schneider M, Schwartz M, Straub C, Toon G, Twigg LW, Walker K, Whiteman DN. 2012. Validation of MIPAS IMK/IAA temperature, water vapor, and ozone profiles with MOHAVE-2009 campaign measurements. Atmos. Measur. Technol. 5: 289-320, DOI: 10.5194/amt-5-289-2012

Streibel M, Rex M, von der Gathen P, Lehmann R, Harris NRP, Braathen GO, Reimer E, Deckelmann H, Chipperfield M, Millard G, Allaart M, Andersen SB, Claude H, Davies J, De Backer H, Dier H, Dorokov V, Fast H, Gerding M, Kyrö E, Litynska Z, Moore D, Moran E, Nagai T, Nakane H, Parrondo C, Skrivankova P, Stübi R, Vaughan G, Viatte P, Yushkov V. 2006. Chemical ozone loss in the Arctic winter 2002/2003 determined with MATCH. Atmos. Chem. Phys. 6: 2783-2792, DOI: 10.5194/acp-6-2783-2006

Talagrand O. 1997. Assimilation of observations, an introduction. J. Meteorol. Soc. Japan. 75: 191-209.

Thompson AM, Oltmans SJ, Tarasick DW, von der Gathen P, Smit HGJ, Witte JC. 2011. Strategic ozone sounding networks: Review of design and accomplishments, Atmospheric Environment. J. Atmos. Env. 45: 2145-2163, DOI: 10.1016/j.atmosenv.2010.05.002

Tilmes S, Müller R, Groö̈ JU, Höpfner M, Toon GC, Russell JM. 2003. Very early chlorine activation and ozone loss in the Arctic winter 2002/2003. J. Geophys. Res. 30: (2201) DOI: 10.1029/2003GL018079

Waters JW, Froidevaux L, Jarnot RF, Read WG, Pickett HM, Harwood RS, Cofield RE, Filipiak MJ, Flower DA, Livesey NJ, Manney GL, Pumphrey HC, Santee ML, Siegel PH, Wu DL. 2004. 'An overview of the EOS MLS Experiment'. ATBD-MLS-01, JPL D-15 745. Jet Propulsion Laboratory: Pasadena, CA.

WCRP. 1998. Assessment of Trends in the Vertical Distribution of Ozone. Harris N, Hudson R, Phillips C (eds). SPARC Report 1, WMO Global Ozone Research and Monitoring Project Report 43. WCRP/WMO Geneva, Switzerland.

Weaver A, Courtier P. 2001. Correlation modelling on the sphere using a generalized diffusion equation. Q. J. R. Meteorol. Soc. 127: 1815-1846.

WMO. 2007. Global Atmosphere Watch (GAW) Strategic Plan: 2008-2015. GAW Report No. 172, WMO TD No. 1384, WMO: Geneva, Switzerland.

WMO. 2011. Quality Assurance and Quality Control for Ozonesonde Measurements in GAW. GAW Report No. 201, WMO: Geneva, Switzerland. 